\title{
ASSESSMENT THE SAFETY POLICY MANAGEMENT FOR BUILDING CONSTRUCTION COMPANIES IN JORDAN
}

\author{
Faidhi A-R S Alubaid ${ }^{2 *}$, Rami H F Alhadeethi ${ }^{2}$, Anas J Mohamed ${ }^{3}$ \\ ${ }^{1}$ Isra University, Amman, Jordan \\ 2 Jordan University, Amman, Jordan \\ ${ }^{3}$ Civil Engineering, Berlin, Germany
}

In Jordan the building construction industry is considered to be one of the most significant industries in terms of contributing to economy, and also in terms of its impact on health and safety of the working people. Construction industry is so important for both sides the socially and economically. At the same time, the construction industry, is also known to be the most hazardous. There for it is essential to investigate and assess the factors effecting safety policy of building construction companies in Jordan, and identifying the level of attention in applying the safety related factors. This research identifies seven of these factors that have the greatest impact to arise. Subsequently, a questionnaire survey was presented into 64 question. The questionnaire survey was distributed to $179\left(1^{\text {st }}, 2^{\text {nd }}\right.$ and $3^{\text {rd }}$ degree $)$ companies which provided by Jordanian construction contractors association. Statistical analysis was carried out to 145 responding companies by employing the (SPSS) program. Data related to safety policy management were analyzed and discussed in details.

Key words: safety policy management, construction projects management, statistical analysis

\section{INTRODUCTION}

The building construction industry considers important sector of Jordan economy, especially regarding its potential employment opportunities. But incidents, accidents, fatalities and injuries continue to happen unrestricted on the construction sites at constantly with high rates.

The construction industry tends to have a low understanding and ignorance for the benefits of long term safety practices, whilst the project managements often gives little attention to health and safety, resulting in more costs.

Construction projects are characterized by many unique and exceptional factors, such as exposure to weather conditions, frequent rotations of work team, high proportions of temporary workers and unskilled. Construction sites, unlike other production and manufacture facilities, undergo changes in topology, topography and work conditions such temperature and wind throughout the projects duration. These features and characteristics make managing building construction project site safety process more difficult than managing safety and health in manufacturing factories or plants.

This study is created in associate with the research carried by Mohamed [1] and the objectives are set to fulfill; First Evaluating the current status of factors effecting safety policy of building construction companies in Jordan, and identifying the level of attention in applying the safety related factors. Second Determining the factors affecting the improvement of safety management.

\section{LITERATURE REVIEW}

Various literatures related to the projects are reviewed.
Some researchers in many countries have identified several leading occupational health and safety risk assessment methods and models. None among the existing studies has been done to investigate extensively the safety policy management system for building construction companies in Jordan.

El-Mashaleh, et al. [2] examine safety management in the Jordanian construction industry. The study collects data from general construction contractors. It reveals several factors of poor safety management. Among these are lack of safety training, rare safety meetings, rare safety inspections, safety protection measures are missing, workers hesitate to use safety equipment, high rates of labor turnover and noncompliance with safety rules and legislation.

Senouci, et al. [3] identify safety issues in Qatari jobsites, and to use risk management techniques to minimize the impacts of the risk factors. The risk assessment was addressed through safety questionnaires to rank the risk factors in order to guide the application of risk management. As a conclusion, the practice of safety risk management must be enhanced in the Qatari construction industry. More training, seminars, and workshops should be conducted by construction companies to familiarize employees about the concept of safety risk management. Al Haadir [4] aiming into identifying the critical factors affecting the successful implementation of safety programs among construction companies in Saudi Arabia. Using AHP analysis technique and Pareto principle, the cumulative average AHP weights of critical safety factors suggested seven critical factors that can account for $80 \%$ of the successful implementation of safety programs in construction companies. These factors are: (1) 
management support; (2) clear and reasonable objectives; (3) Personal attitude; (4) teamwork; (5) effective enforcement; (6) safety training; and (7) suitable supervision. Zolfagharian et al. [5] revealed that the difference was not significant in frequency and severity of accidents between developed and developing countries that were studied in this research. They also found that there was a lack or shortage of safety forward trends and attitudes, as well as a lack of awareness of safety regulations, poor awareness of safety for project managers, and lack of knowledge about hazards with the most construction risk in projects sites.

El-Nagar et al. [6] first, identify the main factors that can be considered as safety performance indicators for the construction projects in Egypt. Second, they develop a safety performance index for the Egyptian construction projects. A questionnaire survey was conducted on 238 contractors and statistical analyses were carried out. The results also showed that some of the high impact factors (safety training and plan) were not to have the importance that deserve. Hasan \& Jha [7] carried out some statistic on safety provisions were collected from 32 construction projects in India, which include both types of contracts, those with safety I/P provisions and those without them. The six factors extracted by carrying out factor analysis are: incentive distribution method, proper labor training, special attention to risky situations, role of safety committee and sub-contractors, specialized works and safety equipment. If taken care of, these attributes have the potential to improve the safety performance in construction projects.

Aksorn \& Hadikusumo [8] identified and ranked in their study 16 Critical Success Factors for the implementation of safety programs based on their influence degree in the construction industry in Thailand. The important factors are: management support, teamwork, realistic and clear goals, efficient enforcement plan, program evaluation, delegation of responsibility and authority, proper supervision, positive group norms, sufficient resource allocation, and continuing employee participation.

Nord et al. [9] collected data from a sample of Swedish manufacturing companies, to investigate factors like company size, safety culture, and different measures of financial performance may be related to the quality of occupational health and safety management (OHSM) practices in companies. The statistical analysis was performed with ordinal regression analysis using generalized estimating equations. This study has found that company size, safety culture, and creditworthiness are associated with better, as well as worse, OHSM practices in companies.

Chen et al. [10] examined the role of safety climate and individual resilience in safety performance and job stress in the Canadian construction industry. The research was based on 837 surveys collected in Ontario. Structural equation modeling (SEM) techniques were used to explore the impact of individual resilience and safety climate on physical safety outcomes and on psychological stress among construction workers. Results show that safety climate affects construction workers' safety performance and also indirectly affects their psychological stress.

Sunindijoa [11] and Ozmec et al. [12] investigate managements for small companies in Australia and Denmark. They found that safety issues were rarely shared or communicated as a common issue within the companies. All contributors in the industry have important roles to play to change the customs and culture in the industry so that small construction companies are supported in their effort to improve their safety performance.

Ayessaki \& Smallwood [13] concluded that construction project managers in South Africa have a major role to play in terms of influencing worker performance through H\&S interventionsduring the design, procurement, and construction processes, however, there is potential to enhance such influence. Recommendations include that CPMs should raise client awareness with respect to worker $\mathrm{H} \& \mathrm{~S}$ and welfare facilities.

Endroyo et al. [14] created the model of Pre-Construction Safety Planning of evaluation to the several medium high rise building projects in Indonesia. the results of research, are the model for evaluating the maturity of PCSP in radar diagram.

\section{RESEARCH METHODOLOGY}

Achieving the objective of this research is maintained by designing a questionnaire establishing sample size, validity content, pilot study, reliability and analyzing and discussing the data which were collected by questionnaire using SPSS program. The questionnaire was designed in four stages, Initial questionnaire list, expert review, pilot questionnaire, and final questionnaire list. Based on extensive literature review, the researchers have gathered 7 main factors effecting construction safety contain sub factors or elements to be included in the research questionnaire. The study will focus on the projects of building construction contracting companies (first, second and third degree) and investigate the safety status when compare collected data. The questionnaire final form was finalized for utilize in the survey, comprised demographic information presented into 64 question see Table-5. The five Likert scales which is the procedure that used in answering the questions in the questionnaires to obtain participant's preferences or degree of agreement with a statement or set of statements according to the importance of each item as shown in Table 1.

Table 1: Degree of Importance

\begin{tabular}{|c|c|c|c|c|c|}
\hline Category & Strongly Agree & Agree & Neutral & Disagree & Strongly Disagree \\
\hline Scale & 5 & 4 & 3 & 2 & 1 \\
\hline
\end{tabular}


The selection of the research samples was based on selecting populations size from $\left(1^{\text {st }}, 2^{\text {nd }}\right.$, and $3^{\text {rd }}$ degree $)$ companies specialized in building which it provided by Jordanian construction contractors association, as shown in Table 2.

The size of the sample required from the target population was determine according to Israel [15];

$\mathbf{n}=\frac{\mathrm{N}}{1+\mathrm{N}(e)^{2}}$

Where; $\mathrm{n}$ the sample size. $\mathrm{N}$ the population size. e the desired accuracy level $=0.05$.

Over 179 questionnaire forms were distributed, 145 were responded, weight for each companies' specialist is shown in the following Table 3.

\section{Statistical analysis}

Qualitative and quantitative data analysis methods were used to analyze the data; it was carried out by employing the (SPSS) programVersion 17.

\section{Reliability analysis}

Measures the consistency over time and over similar samples expectedly, a reliable instrument for a piece of research should produce same data from similar respondents over time; George and Mallery [16]. Cronbach's coefficient $(\alpha)$ was calculated to estimate the internal consistency of reliability of a measurement scale. Nor-
Table 2: Company Distribution according to classification

\begin{tabular}{|c|c|c|}
\hline No. & $\begin{array}{c}\text { Building companies } \\
\text { classification }\end{array}$ & No. of companies \\
\hline 1 & $1^{\text {st }}$ & 72 \\
\hline 2 & $2^{\text {nd }}$ & 49 \\
\hline 3 & $3^{\text {rd }}$ & 91 \\
\hline
\end{tabular}

mally ranges between 0 and 1.0, the closer cronbach's alpha coefficient is to 1.0 the greater the internal consistency of the items in the scale, based upon the following Equation;

$$
\alpha=\frac{\mathrm{K}}{\mathrm{K}-1} \cdot\left(1-\frac{\sum \mathrm{sd}^{2}}{\mathrm{sd}^{2}}\right)
$$

Where; $\mathrm{K}$ the number of questions. $\Sigma \mathrm{sd}^{2}$ the summation of standard variation square.

$\mathrm{sd}^{2}$ the square of total standard variation. The limitations of $\alpha$ where classified in Table 4.

The draft of the questionnaires was presented to eight expertise in academic and practical fields, to assess the clarity and comprehensiveness of each statement and how it is related to the elements that are need to be measured.

Table 5 shows the values of reliability concerning the quality control factors in construction projects. The overall (questionnaire) reliability value was $(0.919)$, and these values reflect a good reliability indication.

Table 3: Weight of sample size

\begin{tabular}{|c|c|c|c|c|}
\hline No. & $\begin{array}{c}\text { Company } \\
\text { classification }\end{array}$ & $\begin{array}{c}\text { number of } \\
\text { companies }\end{array}$ & $\begin{array}{c}\text { The sample } \\
\text { size number }\end{array}$ & $\begin{array}{c}\text { The sample } \\
\text { size respond }\end{array}$ \\
\hline 1 & $1^{\text {st }}$ & 72 & 61 & 52 \\
\hline 2 & $2^{\text {nd }}$ & 49 & 44 & 38 \\
\hline 3 & $3^{\text {rd }}$ & 91 & 74 & 55 \\
\hline
\end{tabular}

Table 4: Weight of sample size

\begin{tabular}{|c|c|c|c|c|c|c|}
\hline Criteria & Excellent & Good & Acceptable & Questionable & Poor & Unacceptable \\
\hline $\begin{array}{c}\text { Cronbach's } \\
\text { Alpha }\end{array}$ & $(\alpha)>0.9$ & $0.9-0.8$ & $0.8-0.7$ & $0.7-0.6$ & $0.6-0.5$ & $(\alpha)<0.5$ \\
\hline
\end{tabular}

Table 5: Reliability of factors affecting safety management in Building construction companies

\begin{tabular}{|c|c|c|c|}
\hline No. & Factors & No. of elements & Reliability \\
\hline 1 & Building site safety procedures & 11 & 0.837 \\
\hline 2 & Company safety policy & 16 & 0.883 \\
\hline 3 & Rewards and penalties & 10 & 0.740 \\
\hline 4 & Workforce human factor & 7 & 0.725 \\
\hline 5 & Safety equipment and PPE & 8 & 0.816 \\
\hline 6 & Practical safety measures & 7 & 0.743 \\
\hline 7 & Project environment & 5 & 0.777 \\
\hline & Dependent variable & 7 & 0.834 \\
\hline Overall factors & $\mathbf{7 1}$ & $\mathbf{0 . 9 1 9}$ & \\
\hline
\end{tabular}




\section{Data analysis for quality control factors}

The values of means, standard deviations, relative importance and correlation coefficient was calculated following MacMillan [17] and relative importance index after lyer \& Jha [18].

1. Mean; the mean value is the most common measure of central tendency.

$$
\text { Mean }=\frac{1}{n} \sum_{i=1}^{n}(f i * x i)
$$

Where; fi the number of respondents who answer the ith option. $\mathrm{Xi}$ the weight that assigned to ith option. $\mathrm{n}$ the total number of respondents.

2. Standard Deviation (SD) gives an idea of how close the entire set of data is to the mean value. Data sets with a small standard deviation have tightly grouped, precise data.

$\mathrm{SD}=\sqrt{\frac{1}{n-1} \sum_{i=1}^{i=n}(x i-\bar{x})^{2}}$

Where; $x i$ the weight that assigned to $\mathrm{i}$ th option. $\bar{x}$ the mean value. $\mathrm{n}$ the total number of respondents.
3. Relative Importance Index (RII) methods are used to determine the ranks of all safety factors.

$\mathrm{RII}=\frac{\Sigma \mathrm{W}}{\mathrm{A} * \mathrm{~N}}$

Where; W the weight given to each factor by the respondents (ranging from 1 to 5 ).

A the highest weight (i.e. 5 in this case). $\mathrm{N}$ the total number of respondents.

4. Correlation Coefficient $(R)$ The linear correlation coefficient is a test that can be used to see if there is a linear relationship between two variables. The range of $(R)$ is from (-1 to 1$)$. If the $(R)$ value is close to $(-1)$, then the relationship is considered anti-correlated, or has a negative slope.

$\mathrm{R}=\frac{\sum(\mathrm{xi}-\overline{\mathrm{x}})(\mathrm{yi}-\overline{\mathrm{y}})}{\sqrt{\sum(\mathrm{xi}-\overline{\mathrm{x}})^{2}} \sqrt{\sum(\mathrm{yi}-\overline{\mathrm{y}})^{2}}}$

Where; $x i$ the weight that assigned to $i$ th option. $\bar{x}$ the mean value of $x$-axis. $\bar{y}$ the mean value of $y$-axis.

All the statistical analysis data for factors effecting safety management system in building construction companies are presented in Table 6:

Table 6: Data Analysis for the safety management system factors

\begin{tabular}{|c|c|c|c|c|c|c|}
\hline $\begin{array}{l}\text { Item } \\
\text { No. }\end{array}$ & $\begin{array}{l}\text { (1) Sub factors for Building site safety } \\
\text { procedures }\end{array}$ & $\begin{array}{l}\text { Company } \\
\text { Degree }\end{array}$ & Mean & SD & RII \% & Rank \\
\hline \multirow{3}{*}{1} & \multirow{3}{*}{$\begin{array}{l}\text { The illustrative boards and signs for safety } \\
\text { instructions are installed in the project site. }\end{array}$} & $1^{\text {st }}$ & 4.71 & 0.46 & 94.20 & 5 \\
\hline & & $2^{\text {nd }}$ & 4.16 & 0.44 & 83.20 & 5 \\
\hline & & $3^{\text {rd }}$ & 3.07 & 0.47 & 61.40 & 3 \\
\hline \multirow{3}{*}{2} & \multirow{3}{*}{$\begin{array}{l}\text { The general clear layout and scheme for the } \\
\text { project site is available in most places. }\end{array}$} & $1^{\text {st }}$ & 4.69 & 0.47 & 93.80 & 6 \\
\hline & & $2^{\text {nd }}$ & 2.13 & 1.36 & 42.60 & 11 \\
\hline & & $3^{\text {rd }}$ & 2.55 & 0.50 & 51.00 & 5 \\
\hline \multirow{3}{*}{3.} & \multirow{3}{*}{$\begin{array}{l}\text { Continuous unexpected inspections by safety } \\
\text { officers into the worker's safety requirements } \\
\text { at the project site. }\end{array}$} & $1^{\text {st }}$ & 3.94 & 0.87 & 78.80 & 10 \\
\hline & & $2^{\text {nd }}$ & 3.74 & 0.60 & 74.80 & 7 \\
\hline & & $3^{\text {rd }}$ & 2.67 & 0.94 & 53.40 & 4 \\
\hline \multirow{3}{*}{4} & \multirow{3}{*}{$\begin{array}{l}\text { Daily meetings are held to discuss the safety } \\
\text { requirements with employees at least for } 10 \\
\text { minutes at the beginning of working day. }\end{array}$} & $1^{\text {st }}$ & 2.88 & 1.62 & 57.60 & 11 \\
\hline & & $2^{\text {nd }}$ & 2.29 & 1.14 & 45.80 & 10 \\
\hline & & $3^{\text {rd }}$ & 1.35 & 0.64 & 27.00 & 11 \\
\hline \multirow{3}{*}{5} & \multirow{3}{*}{$\begin{array}{l}\text { Continuous training and education are avail- } \\
\text { able into the application of safety regulations } \\
\text { at the project site. }\end{array}$} & $1^{\mathrm{st}}$ & 4.63 & 0.49 & 92.60 & 8 \\
\hline & & $2^{\text {nd }}$ & 3.79 & 0.53 & 75.80 & 6 \\
\hline & & $3^{\text {rd }}$ & 2.33 & 0.75 & 46.60 & 7 \\
\hline \multirow{3}{*}{6} & \multirow{3}{*}{$\begin{array}{l}\text { Wired or wireless communication means are } \\
\text { available to follow the safety instructions at } \\
\text { the project site. }\end{array}$} & $1^{\text {st }}$ & 4.94 & 0.24 & 98.80 & 1 \\
\hline & & $2^{\text {nd }}$ & 4.32 & 0.53 & 86.40 & 3 \\
\hline & & $3^{\text {rd }}$ & 3.11 & 0.46 & 62.20 & 2 \\
\hline \multirow{3}{*}{7} & \multirow{3}{*}{$\begin{array}{l}\text { Cameras are available to monitor the imple- } \\
\text { mentation of safety instructions at the project } \\
\text { site. }\end{array}$} & $1^{\text {st }}$ & 4.67 & 0.47 & 93.40 & 7 \\
\hline & & $2^{\text {nd }}$ & 4.18 & 0.80 & 83.60 & 4 \\
\hline & & $3^{\text {rd }}$ & 2.42 & 0.74 & 48.40 & 6 \\
\hline
\end{tabular}




\begin{tabular}{|c|c|c|c|c|c|c|}
\hline $\begin{array}{l}\text { Item } \\
\text { No. }\end{array}$ & $\begin{array}{l}\text { (1) Sub factors for Building site safety } \\
\text { procedures }\end{array}$ & $\begin{array}{l}\text { Company } \\
\text { Degree }\end{array}$ & Mean & SD & RII \% & Rank \\
\hline \multirow{3}{*}{8} & \multirow{3}{*}{$\begin{array}{l}\text { First aid trained cadre, dedicated room and } \\
\text { first aid kit are available at the project site. }\end{array}$} & $1^{\text {st }}$ & 4.90 & 0.30 & 98.00 & 3 \\
\hline & & $2^{\text {nd }}$ & 3.50 & 0.86 & 70.00 & 8 \\
\hline & & $3^{\text {rd }}$ & 1.65 & 1.13 & 33.00 & 9 \\
\hline \multirow{3}{*}{9} & \multirow{3}{*}{$\begin{array}{l}\text { Sufficient authority is available for safety } \\
\text { officers and supervisors to deal with workers } \\
\text { violate safety instructions on the project site. }\end{array}$} & $1^{\text {st }}$ & 3.96 & 1.40 & 79.20 & 9 \\
\hline & & $2^{\text {nd }}$ & 2.74 & 1.13 & 54.80 & 9 \\
\hline & & $3^{\text {rd }}$ & 1.38 & 0.89 & 27.60 & 10 \\
\hline \multirow{3}{*}{10} & \multirow{3}{*}{$\begin{array}{l}\text { Recording \& documentation system is avail- } \\
\text { able to record injuries, accidents and safety } \\
\text { violations at the project site. }\end{array}$} & $1^{\text {st }}$ & 4.88 & 0.32 & 97.60 & 4 \\
\hline & & $2^{\text {nd }}$ & 4.50 & 0.56 & 90.00 & 2 \\
\hline & & $3^{\text {rd }}$ & 3.20 & 0.40 & 64.00 & 1 \\
\hline \multirow{3}{*}{11} & \multirow{3}{*}{$\begin{array}{l}\text { Active and resolute penalties System is avail- } \\
\text { able when violations of safety get occur. }\end{array}$} & $1^{\text {st }}$ & 4.92 & 0.27 & 98.40 & 2 \\
\hline & & $2^{\text {nd }}$ & 4.66 & 0.48 & 93.20 & 1 \\
\hline & & $3^{\text {rd }}$ & 2.25 & 0.64 & 45.00 & 8 \\
\hline & \multirow{3}{*}{$\begin{array}{l}\text { The overall of Building site safety proce- } \\
\text { dures }\end{array}$} & $1^{\text {st }}$ & 4.47 & 0.42 & 89.40 & $\mathrm{R}=0.88$ \\
\hline & & $2^{\text {nd }}$ & 3.64 & 0.34 & 72.80 & $\mathrm{R}=0.55$ \\
\hline & & $3^{\text {rd }}$ & 2.36 & 0.26 & 47.20 & $R=0.92$ \\
\hline & (2) Sub factors forcompany safety policy & $\begin{array}{l}\text { Company } \\
\text { Degree }\end{array}$ & Mean & SD & RII \% & Rank \\
\hline \multirow{3}{*}{12} & \multirow{3}{*}{$\begin{array}{l}\text { Specialized office is available at the company } \\
\text { to follow up application of safety require- } \\
\text { ments and instructions in all projects. }\end{array}$} & $1^{\text {st }}$ & 4.58 & 0.50 & 91.60 & 8 \\
\hline & & $2^{\text {nd }}$ & 2.87 & 1.02 & 57.40 & 13 \\
\hline & & $3^{\text {rd }}$ & 1.31 & 0.74 & 26.20 & 13 \\
\hline \multirow{3}{*}{13} & \multirow{3}{*}{$\begin{array}{l}\text { Adequate budget is allocated to provide safe- } \\
\text { ty supplies and guarantee of safety applica- } \\
\text { tion in the company. }\end{array}$} & $1^{\text {st }}$ & 4.40 & 0.50 & 88.00 & 10 \\
\hline & & $2^{\text {nd }}$ & 3.24 & 0.71 & 64.80 & 10 \\
\hline & & $3^{\text {rd }}$ & 1.22 & 0.66 & 24.40 & 14 \\
\hline \multirow{3}{*}{14} & \multirow{3}{*}{$\begin{array}{l}\text { The company having policy and clear vision } \\
\text { for the effective application of safety require- } \\
\text { ments in all locations. }\end{array}$} & $1^{\text {st }}$ & 4.75 & 0.44 & 95.00 & 6 \\
\hline & & $2^{\text {nd }}$ & 3.37 & 0.71 & 67.40 & 7 \\
\hline & & $3^{\text {rd }}$ & 2.11 & 0.50 & 42.20 & 8 \\
\hline \multirow{3}{*}{15} & \multirow{3}{*}{$\begin{array}{l}\text { There is a constant monitoring of worker vio- } \\
\text { lations for safety requirements at the site. }\end{array}$} & $1^{\text {st }}$ & 4.83 & 0.38 & 96.60 & 5 \\
\hline & & $2^{\text {nd }}$ & 4.32 & 0.47 & 86.40 & 4 \\
\hline & & $3^{\text {rd }}$ & 2.44 & 0.83 & 48.80 & 5 \\
\hline \multirow{3}{*}{16} & \multirow{3}{*}{$\begin{array}{l}\text { The company prepared a well written bro- } \\
\text { chure about the safety requirement applica- } \\
\text { tion. }\end{array}$} & $1^{\text {st }}$ & 3.87 & 0.97 & 77.40 & 13 \\
\hline & & $2^{\text {nd }}$ & 3.26 & 0.45 & 65.20 & 9 \\
\hline & & $3^{\text {rd }}$ & 1.45 & 0.66 & 29.00 & 10 \\
\hline \multirow{3}{*}{17} & \multirow{3}{*}{$\begin{array}{l}\text { Safety policy revealed with clear format and } \\
\text { understood to all company staff. }\end{array}$} & $1^{\text {st }}$ & 3.90 & 1.40 & 78.00 & 12 \\
\hline & & $2^{\text {nd }}$ & 3.18 & 0.80 & 63.60 & 12 \\
\hline & & $3^{\text {rd }}$ & 1.44 & 0.60 & 28.80 & 11 \\
\hline
\end{tabular}




\begin{tabular}{|c|c|c|c|c|c|c|}
\hline $\begin{array}{l}\text { Item } \\
\text { No. }\end{array}$ & (2) Sub factors forcompany safety policy & $\begin{array}{l}\text { Company } \\
\text { Degree }\end{array}$ & Mean & SD & RII \% & Rank \\
\hline \multirow{3}{*}{18} & \multirow{3}{*}{$\begin{array}{l}\text { Top management and site management } \\
\text { strongly Support the implementation of safety } \\
\text { regulations. }\end{array}$} & $1^{\text {st }}$ & 4.62 & 0.49 & 92.40 & 7 \\
\hline & & $2^{\text {nd }}$ & 4.16 & 0.37 & 83.20 & 5 \\
\hline & & $3^{\text {rd }}$ & 2.24 & 0.58 & 44.80 & 7 \\
\hline \multirow{3}{*}{19} & \multirow{3}{*}{$\begin{array}{l}\text { Overtime working hours is applied only in } \\
\text { the necessary cases. This to avoid the high } \\
\text { stresses on workers. }\end{array}$} & $1^{\text {st }}$ & 3.44 & 0.67 & 68.80 & 14 \\
\hline & & $2^{\text {nd }}$ & 2.84 & 0.44 & 56.80 & 14 \\
\hline & & $3^{\text {rd }}$ & 1.42 & 0.69 & 28.40 & 12 \\
\hline \multirow{3}{*}{20} & \multirow{3}{*}{$\begin{array}{l}\text { The company follows continuous improve- } \\
\text { ment policy in applying safety requirements. }\end{array}$} & $1^{\text {st }}$ & 4.44 & 0.89 & 88.80 & 9 \\
\hline & & $2^{\text {nd }}$ & 3.24 & 0.88 & 64.80 & 10 \\
\hline & & $3^{\text {rd }}$ & 1.58 & 0.60 & 31.60 & 9 \\
\hline \multirow{3}{*}{21} & \multirow{3}{*}{$\begin{array}{l}\text { The company safety policy was being mod- } \\
\text { ified, reviewed and updated periodically or } \\
\text { annually. }\end{array}$} & $1^{\text {st }}$ & 2.54 & 0.90 & 50.80 & 15 \\
\hline & & $2^{\text {nd }}$ & 1.42 & 0.50 & 28.40 & 15 \\
\hline & & $3^{\text {rd }}$ & 1.22 & 0.46 & 24.40 & 14 \\
\hline \multirow{3}{*}{22} & \multirow{3}{*}{$\begin{array}{l}\text { The company is keen on constructing coop- } \\
\text { eration and teamwork between company staff } \\
\text { to improve safety. }\end{array}$} & $1^{\text {st }}$ & 4.87 & 0.40 & 97.40 & 4 \\
\hline & & $2^{\text {nd }}$ & 4.42 & 0.50 & 88.40 & 3 \\
\hline & & $3^{\text {rd }}$ & 3.62 & 0.87 & 72.40 & 2 \\
\hline \multirow{3}{*}{23} & \multirow{3}{*}{$\begin{array}{l}\text { Everyone on site has the free will and privacy } \\
\text { for reporting imminent incidents or safety } \\
\text { violations. }\end{array}$} & $1^{\text {st }}$ & 4.94 & 0.24 & 98.80 & 1 \\
\hline & & $2^{\text {nd }}$ & 4.97 & 0.16 & 99.40 & 1 \\
\hline & & $3^{\text {rd }}$ & 4.15 & 0.36 & 83.00 & 1 \\
\hline \multirow{3}{*}{24} & \multirow{3}{*}{$\begin{array}{l}\text { The company possesses a management } \\
\text { system for risks, accidents and injuries. }\end{array}$} & $1^{\text {st }}$ & 4.12 & 0.38 & 82.40 & 11 \\
\hline & & $2^{\text {nd }}$ & 3.37 & 0.49 & 67.40 & 7 \\
\hline & & $3^{\text {rd }}$ & 2.40 & 0.60 & 48.00 & 6 \\
\hline \multirow{3}{*}{25} & \multirow{3}{*}{$\begin{array}{l}\text { The company maintains the safety policy } \\
\text { despite its effects on the project time con- } \\
\text { straints. }\end{array}$} & $1^{\text {st }}$ & 4.88 & 0.32 & 97.60 & 3 \\
\hline & & $2^{\text {nd }}$ & 4.76 & 0.43 & 95.20 & 2 \\
\hline & & $3^{\text {rd }}$ & 3.00 & 0.00 & 60.00 & 4 \\
\hline \multirow{3}{*}{26} & \multirow{3}{*}{$\begin{array}{l}\text { The company follows the work safety system } \\
\text { in Jordan, according to the Employment Act } \\
\text { No. } 43 \text { of } 1998 \text {. }\end{array}$} & $1^{\text {st }}$ & 4.90 & 0.30 & 98.00 & 2 \\
\hline & & $2^{\text {nd }}$ & 3.68 & 0.47 & 73.60 & 6 \\
\hline & & $3^{\text {rd }}$ & 3.40 & 0.66 & 68.00 & 3 \\
\hline \multirow{3}{*}{27} & \multirow{3}{*}{$\begin{array}{l}\text { The company follows the standards of the } \\
\text { Occupational Health and Safety Administra- } \\
\text { tion (OSHA) or (OHSAS). }\end{array}$} & $1^{\text {st }}$ & 2.21 & 0.94 & 44.20 & 16 \\
\hline & & $2^{\text {nd }}$ & 1.26 & 0.45 & 25.20 & 16 \\
\hline & & $3^{\text {rd }}$ & 1.13 & 0.34 & 22.60 & 16 \\
\hline & \multirow{3}{*}{ The over all of company safety policy } & $1^{\text {st }}$ & 4.21 & 0.38 & 84.20 & $\mathrm{R}=0.90$ \\
\hline & & $2^{\text {nd }}$ & 3.40 & 0.11 & 68.00 & $\mathrm{R}=0.42$ \\
\hline & & $3^{\text {rd }}$ & 2.13 & 0.39 & 42.60 & $\mathrm{R}=0.93$ \\
\hline
\end{tabular}




\begin{tabular}{|c|c|c|c|c|c|c|}
\hline \multirow{3}{*}{28} & \multirow{3}{*}{$\begin{array}{l}\text { The penalty gradient due to violator or negli- } \\
\text { gent of safety requirements is; Oral warning } \\
\text { with the signing of the warning, then fine, } \\
\text { then dismissed from work. }\end{array}$} & $1^{\mathrm{st}}$ & 3.40 & 0.60 & 68.00 & 9 \\
\hline & & $2^{\text {nd }}$ & 2.84 & 0.89 & 56.80 & 5 \\
\hline & & $3^{\text {rd }}$ & 1.38 & 0.62 & 27.60 & 7 \\
\hline \multirow{3}{*}{29} & \multirow{3}{*}{$\begin{array}{l}\text { The penalization for violating workers to safe- } \\
\text { ty instructions are by fines or penalties. }\end{array}$} & $1^{\text {st }}$ & 4.96 & 0.19 & 99.20 & 1 \\
\hline & & $2^{\text {nd }}$ & 4.84 & 0.37 & 96.80 & 1 \\
\hline & & $3^{\text {rd }}$ & 4.80 & 0.40 & 96.00 & 1 \\
\hline \multirow{3}{*}{30} & \multirow{3}{*}{$\begin{array}{l}\text { Negligent workers for safety instructions are } \\
\text { penalized with oral or written warning or man- } \\
\text { agerial penalty. }\end{array}$} & $1^{\text {st }}$ & 4.79 & 0.41 & 95.80 & 2 \\
\hline & & $2^{\text {nd }}$ & 3.24 & 0.43 & 64.80 & 4 \\
\hline & & $3^{\text {rd }}$ & 3.47 & 0.50 & 69.40 & 3 \\
\hline \multirow{3}{*}{31} & \multirow{3}{*}{$\begin{array}{l}\text { Committed workers to safety instructions are } \\
\text { rewarded with a cash bonus. }\end{array}$} & $1^{\text {st }}$ & 2.23 & 0.43 & 44.60 & 10 \\
\hline & & $2^{\text {nd }}$ & 2.37 & 0.67 & 47.40 & 7 \\
\hline & & $3^{\text {rd }}$ & 1.45 & 0.79 & 29.00 & 5 \\
\hline \multirow{3}{*}{32} & \multirow{3}{*}{$\begin{array}{l}\text { Committed workers to safety instructions are } \\
\text { rewarded with a managerially and morally. }\end{array}$} & $1^{\mathrm{st}}$ & 4.75 & 0.44 & 95.00 & 4 \\
\hline & & $2^{\text {nd }}$ & 3.32 & 0.47 & 66.40 & 3 \\
\hline & & $3^{\text {rd }}$ & 2.25 & 0.52 & 45.00 & 4 \\
\hline \multirow{3}{*}{33} & \multirow{3}{*}{$\begin{array}{l}\text { Subcontractors will be prohibited from } \\
\text { working when he repeatedly violated the site } \\
\text { safety regulations. }\end{array}$} & $1^{\text {st }}$ & 3.81 & 1.24 & 76.20 & 7 \\
\hline & & $2^{\text {nd }}$ & 2.47 & 0.86 & 49.40 & 6 \\
\hline & & $3^{\text {rd }}$ & 1.33 & 0.47 & 26.60 & 9 \\
\hline \multirow{3}{*}{34} & \multirow{3}{*}{$\begin{array}{l}\text { No deal with Subcontractors having bad and } \\
\text { weak previous safety performance record. }\end{array}$} & $1^{\text {st }}$ & 3.65 & 1.23 & 73.00 & 8 \\
\hline & & $2^{\text {nd }}$ & 1.61 & 0.50 & 32.20 & 10 \\
\hline & & $3^{\text {rd }}$ & 1.38 & 0.56 & 27.60 & 7 \\
\hline \multirow{3}{*}{35} & \multirow{3}{*}{$\begin{array}{l}\text { The company received reward due to excel- } \\
\text { lent safety performance. }\end{array}$} & $1^{\text {st }}$ & 2.90 & 1.03 & 58.00 & 5 \\
\hline & & $2^{\text {nd }}$ & 1.79 & 0.41 & 35.80 & 9 \\
\hline & & $3^{\text {rd }}$ & 1.29 & 0.46 & 25.80 & 10 \\
\hline \multirow{3}{*}{36} & \multirow{3}{*}{$\begin{array}{l}\text { The company did not receive a penalty due } \\
\text { to faulty safety performance. }\end{array}$} & $1^{\text {st }}$ & 4.77 & 0.43 & 95.40 & 3 \\
\hline & & $2^{\text {nd }}$ & 4.42 & 0.50 & 88.40 & 2 \\
\hline & & $3^{\text {rd }}$ & 4.24 & 0.43 & 84.80 & 2 \\
\hline \multirow{6}{*}{37} & \multirow{3}{*}{$\begin{array}{l}\text { Safety implementation is an important ele- } \\
\text { ment in the process of the projects awarded } \\
\text { contributions in the company. }\end{array}$} & $1^{\text {st }}$ & 3.87 & 1.52 & 77.40 & 6 \\
\hline & & $2^{\text {nd }}$ & 2.34 & 0.67 & 46.80 & 8 \\
\hline & & $3^{\text {rd }}$ & 1.44 & 0.83 & 28.80 & 6 \\
\hline & \multirow{3}{*}{ The overall of rewards and penalties. } & $1^{\text {st }}$ & 3.91 & 0.41 & 82.20 & $\mathrm{R}=0.88$ \\
\hline & & $2^{\text {nd }}$ & 2.92 & 0.21 & 58.40 & $\mathrm{R}=0.76$ \\
\hline & & $3^{\text {rd }}$ & 2.30 & 0.44 & 46.00 & $\mathrm{R}=0.84$ \\
\hline
\end{tabular}




\begin{tabular}{|c|c|c|c|c|c|c|}
\hline & (4) Sub factors of Workforce Human factor & $\begin{array}{l}\text { Company } \\
\text { Degree }\end{array}$ & Mean & SD & RII \% & Rank \\
\hline \multirow{3}{*}{38} & \multirow{3}{*}{$\begin{array}{l}\text { The workers age has an effect on the appli- } \\
\text { cations of site safety instructions. }\end{array}$} & $1^{\text {st }}$ & 3.58 & 1.72 & 71.60 & 7 \\
\hline & & $2^{\text {nd }}$ & 4.61 & 0.68 & 92.20 & 2 \\
\hline & & $3^{\text {rd }}$ & 4.84 & 0.37 & 96.80 & 2 \\
\hline \multirow{3}{*}{39} & \multirow{3}{*}{$\begin{array}{l}\text { Everybody on site is committed to apply the } \\
\text { safety instructions. }\end{array}$} & $1^{\text {st }}$ & 4.83 & 0.38 & 96.60 & 3 \\
\hline & & $2^{\text {nd }}$ & 2.58 & 0.60 & 51.60 & 7 \\
\hline & & $3^{\text {rd }}$ & 1.24 & 0.61 & 24.80 & 6 \\
\hline \multirow{3}{*}{40} & \multirow{3}{*}{$\begin{array}{l}\text { Frequently changing the work force has an } \\
\text { effect on achieving the safety requirements } \\
\text { and instructions at site. }\end{array}$} & $1^{\text {st }}$ & 3.75 & 1.62 & 75.00 & 6 \\
\hline & & $2^{\text {nd }}$ & 4.26 & 0.45 & 85.20 & 5 \\
\hline & & $3^{\text {rd }}$ & 4.95 & 0.23 & 99.00 & 1 \\
\hline \multirow{3}{*}{41} & \multirow{3}{*}{$\begin{array}{l}\text { Education and learning scales of workers } \\
\text { has an effect on the application of site safety } \\
\text { requirements. }\end{array}$} & $1^{\text {st }}$ & 4.85 & 0.41 & 97.00 & 2 \\
\hline & & $2^{\text {nd }}$ & 4.42 & 0.50 & 88.40 & 3 \\
\hline & & $3^{\text {rd }}$ & 4.60 & 0.49 & 92.00 & 4 \\
\hline \multirow{3}{*}{42} & \multirow{3}{*}{$\begin{array}{l}\text { Ignorance has an effect on workers' applica- } \\
\text { tion of safety requirements and instructions } \\
\text { on site. }\end{array}$} & $1^{\text {st }}$ & 4.94 & 0.24 & 98.80 & 1 \\
\hline & & $2^{\text {nd }}$ & 4.87 & 0.34 & 97.40 & 1 \\
\hline & & $3^{\text {rd }}$ & 4.73 & 0.45 & 94.60 & 3 \\
\hline \multirow{3}{*}{43} & \multirow{3}{*}{$\begin{array}{l}\text { Expats from outside Jordan and rural areas } \\
\text { do not adhere to the application of safety } \\
\text { instructions at work. }\end{array}$} & $1^{\text {st }}$ & 4.65 & 0.65 & 93.00 & 4 \\
\hline & & $2^{\text {nd }}$ & 4.32 & 0.47 & 86.40 & 4 \\
\hline & & $3^{\text {rd }}$ & 3.45 & 0.69 & 69.00 & 5 \\
\hline \multirow{3}{*}{44} & \multirow{3}{*}{$\begin{array}{l}\text { The selection of workers and subcontractors } \\
\text { basically follows the availability of the condi- } \\
\text { tions and requirements of safety. }\end{array}$} & $1^{\text {st }}$ & 4.38 & 0.99 & 87.60 & 5 \\
\hline & & $2^{\text {nd }}$ & 3.37 & 0.49 & 67.40 & 6 \\
\hline & & $3^{\text {rd }}$ & 1.05 & 0.23 & 21.00 & 7 \\
\hline & \multirow{3}{*}{ The Overall of Workforce human factor } & $1^{\text {st }}$ & 4.43 & 0.63 & 88.60 & $\mathrm{R}=0.77$ \\
\hline & & $2^{\text {nd }}$ & 4.06 & 0.21 & 81.20 & $\mathrm{R}=0.77$ \\
\hline & & $3^{\text {rd }}$ & 3.55 & 0.22 & 71.00 & $R=0.87$ \\
\hline & $\begin{array}{l}\text { (5) Sub factors of Safety equipment and } \\
\text { PPE }\end{array}$ & $\begin{array}{l}\text { Company } \\
\text { Degree }\end{array}$ & Mean & SD & RII \% & Rank \\
\hline \multirow{3}{*}{45} & \multirow{3}{*}{$\begin{array}{l}\text { Periodical maintenance for Safety equipment } \\
\text { and PPEs are existing. }\end{array}$} & $1^{\text {st }}$ & 4.88 & 0.32 & 97.60 & 2 \\
\hline & & $2^{\text {nd }}$ & 3.26 & 0.64 & 65.20 & 8 \\
\hline & & $3^{\text {rd }}$ & 2.38 & 0.53 & 47.60 & 4 \\
\hline \multirow{3}{*}{46} & \multirow{3}{*}{$\begin{array}{l}\text { All instruments, equipment, and supplies for } \\
\text { safety requirements are available in site. }\end{array}$} & $1^{\text {st }}$ & 4.92 & 0.27 & 98.40 & 1 \\
\hline & & $2^{\text {nd }}$ & 4.50 & 0.51 & 90.00 & 2 \\
\hline & & $3^{\text {rd }}$ & 2.56 & 0.79 & 51.20 & 3 \\
\hline \multirow{3}{*}{47} & \multirow{3}{*}{$\begin{array}{l}\text { Disposal of old and damaged Safety equip- } \\
\text { ment and PPEs from site. }\end{array}$} & $1^{\text {st }}$ & 4.87 & 0.34 & 97.40 & 3 \\
\hline & & $2^{\text {nd }}$ & 4.63 & 0.49 & 92.60 & 1 \\
\hline & & $3^{\text {rd }}$ & 4.04 & 0.33 & 80.80 & 1 \\
\hline
\end{tabular}




\begin{tabular}{|c|c|c|c|c|c|c|}
\hline \multirow{3}{*}{48} & \multirow{3}{*}{$\begin{array}{l}\text { The effective techniques and modern and } \\
\text { functioning equipment for safety are available } \\
\text { in site. }\end{array}$} & $1^{\text {st }}$ & 4.87 & 0.34 & 97.40 & 4 \\
\hline & & $2^{\text {nd }}$ & 3.76 & 0.63 & 75.20 & 5 \\
\hline & & $3^{\text {rd }}$ & 2.36 & 0.80 & 47.20 & 5 \\
\hline \multirow{3}{*}{49} & \multirow{3}{*}{$\begin{array}{l}\text { The constructions materials utilize on site } \\
\text { have no dangerous to safety regulations. }\end{array}$} & $1^{\text {st }}$ & 4.31 & 0.64 & 86.20 & 8 \\
\hline & & $2^{\text {nd }}$ & 4.32 & 0.47 & 86.40 & 3 \\
\hline & & $3^{\text {rd }}$ & 3.80 & 0.49 & 76.00 & 2 \\
\hline \multirow{3}{*}{50} & \multirow{3}{*}{$\begin{array}{l}\text { The company is dedicated to trains the safety } \\
\text { officers to the latest technology. }\end{array}$} & $1^{\text {st }}$ & 4.77 & 0.43 & 95.40 & 5 \\
\hline & & $2^{\text {nd }}$ & 3.61 & 0.72 & 72.20 & 6 \\
\hline & & $3^{\text {rd }}$ & 1.20 & 0.40 & 24.00 & 8 \\
\hline \multirow{3}{*}{51} & \multirow{3}{*}{$\begin{array}{l}\text { Safety problems does not occur because of } \\
\text { Safety equipment and PPE used by workers } \\
\text { in the site. }\end{array}$} & $1^{\text {st }}$ & 4.60 & 0.50 & 92.00 & 7 \\
\hline & & $2^{\text {nd }}$ & 3.82 & 1.04 & 76.40 & 4 \\
\hline & & $3^{\text {rd }}$ & 2.29 & 0.53 & 45.80 & 6 \\
\hline \multirow{3}{*}{52} & \multirow{3}{*}{$\begin{array}{l}\text { Company utilizes the expertise from safety } \\
\text { corporations proficient in the similar contract- } \\
\text { ing companies. }\end{array}$} & $1^{\text {st }}$ & 4.69 & 0.47 & 93.80 & 6 \\
\hline & & $2^{\text {nd }}$ & 3.34 & 0.48 & 66.80 & 7 \\
\hline & & $3^{\text {rd }}$ & 1.76 & 0.86 & 35.20 & 7 \\
\hline & \multirow{3}{*}{ The Overall of Safety equipment and PPE } & $1^{\text {st }}$ & 4.74 & 0.16 & 94.80 & $\mathrm{R}=0.48$ \\
\hline & & $2^{\text {nd }}$ & 3.90 & 0.26 & 78.00 & $\mathrm{R}=0.47$ \\
\hline & & $3^{\text {rd }}$ & 2.55 & 0.22 & 51.00 & $R=0.58$ \\
\hline & $\begin{array}{l}\text { (6) Sub factors of Practical safety mea- } \\
\text { sures }\end{array}$ & $\begin{array}{l}\text { Company } \\
\text { Degree }\end{array}$ & Mean & SD & RII \% & Rank \\
\hline \multirow{3}{*}{53} & \multirow{3}{*}{$\begin{array}{l}\text { Hazards and injuries which occur on con- } \\
\text { struction site are classified. }\end{array}$} & $1^{\text {st }}$ & 4.81 & 0.40 & 96.20 & 3 \\
\hline & & $2^{\text {nd }}$ & 3.24 & 0.43 & 64.80 & 2 \\
\hline & & $3^{\text {rd }}$ & 2.40 & 0.78 & 48,00 & 2 \\
\hline \multirow{3}{*}{54} & \multirow{3}{*}{$\begin{array}{l}\text { Identification of risks and injuries and avoid- } \\
\text { ing them integrated with the progress of the } \\
\text { work schedule. }\end{array}$} & $1^{\text {st }}$ & 4.88 & 0.32 & 97.60 & 2 \\
\hline & & $2^{\text {nd }}$ & 2.79 & 0.78 & 55.80 & 5 \\
\hline & & $3^{\text {rd }}$ & 1.45 & 0.81 & 29.00 & 6 \\
\hline \multirow{3}{*}{55} & \multirow{3}{*}{$\begin{array}{l}\text { Risk assessment is carried out to avoid its } \\
\text { happening at project site in the future. }\end{array}$} & $1^{\text {st }}$ & 4.31 & 1.02 & 86.20 & 5 \\
\hline & & $2^{\text {nd }}$ & 2.89 & 0.56 & 57.80 & 4 \\
\hline & & $3^{\text {rd }}$ & 2.24 & 0.58 & 44.80 & 3 \\
\hline \multirow{3}{*}{56} & \multirow{3}{*}{$\begin{array}{l}\text { An approved emergency plan is available in } \\
\text { site to succeeding safety requirements. }\end{array}$} & $1^{\text {st }}$ & 3.19 & 1.01 & 63.80 & 7 \\
\hline & & $2^{\text {nd }}$ & 2.42 & 0.76 & 48.40 & 6 \\
\hline & & $3^{\text {rd }}$ & 1.16 & 0.46 & 23.20 & 7 \\
\hline \multirow{3}{*}{57} & \multirow{3}{*}{$\begin{array}{l}\text { Increasing the safety team with increasing } \\
\text { manpower in the company. }\end{array}$} & $1^{\text {st }}$ & 4.98 & 0.14 & 99.60 & 1 \\
\hline & & $2^{\text {nd }}$ & 4.32 & 0.47 & 86.40 & 1 \\
\hline & & $3^{\text {rd }}$ & 2.42 & 0.79 & 48.40 & 1 \\
\hline \multirow{3}{*}{58} & \multirow{3}{*}{$\begin{array}{l}\text { Responding top management and workers to } \\
\text { risks and injuries momentary in the construc- } \\
\text { tion site. }\end{array}$} & $1^{\text {st }}$ & 4.38 & 0.49 & 87.60 & 4 \\
\hline & & $2^{\text {nd }}$ & 3.24 & 0.94 & 64.80 & 2 \\
\hline & & $3^{\text {rd }}$ & 2.20 & 0.52 & 44.00 & 4 \\
\hline
\end{tabular}




\begin{tabular}{|c|c|c|c|c|c|c|}
\hline \multirow{3}{*}{59} & \multirow{3}{*}{$\begin{array}{l}\text { Regular measurements of safety procedures } \\
\text { are available for application in construction } \\
\text { site. }\end{array}$} & $1^{\text {st }}$ & 3.96 & 0.44 & 79.20 & 6 \\
\hline & & $2^{\text {nd }}$ & 2.29 & 0.61 & 45.80 & 7 \\
\hline & & $3^{\text {rd }}$ & 1.53 & 0.77 & 30.60 & 5 \\
\hline & \multirow{3}{*}{ The Overall of Practical safety measures } & $1^{\text {st }}$ & 4.36 & 0.29 & 87.20 & $R=0.10$ \\
\hline & & $2^{\text {nd }}$ & 3.03 & 0.30 & 60.60 & $R=0.51$ \\
\hline & & $3^{\text {rd }}$ & 1.91 & 0.51 & 38.20 & $R=0.33$ \\
\hline & $\begin{array}{l}\text { (7) Sub factors of project environment } \\
\text { factor }\end{array}$ & $\begin{array}{l}\text { Company } \\
\text { Degree }\end{array}$ & Mean & SD & RII \% & Rank \\
\hline \multirow{3}{*}{60} & \multirow{3}{*}{$\begin{array}{l}\text { Working in bad weather cause nocomplica- } \\
\text { tions into the application of safety require- } \\
\text { ments. }\end{array}$} & $1^{\text {st }}$ & 4.31 & 0.58 & 86.20 & 3 \\
\hline & & $2^{\text {nd }}$ & 2.76 & 0.43 & 55.20 & 3 \\
\hline & & $3^{\text {rd }}$ & 1.71 & 1.29 & 34.20 & 3 \\
\hline \multirow{3}{*}{61} & \multirow{3}{*}{$\begin{array}{l}\text { Working in poor lighting during night work } \\
\text { cause no complications into the application of } \\
\text { safety requirements. }\end{array}$} & $1^{\text {st }}$ & 3.56 & 0.78 & 71.20 & 5 \\
\hline & & $2^{\text {nd }}$ & 1.87 & 0.66 & 37.40 & 4 \\
\hline & & $3^{\text {rd }}$ & 1.31 & 0.63 & 26.20 & 5 \\
\hline \multirow{3}{*}{62} & \multirow{3}{*}{$\begin{array}{l}\text { Working in noise and loud sounds in the proj- } \\
\text { ect cause nocomplications into the applica- } \\
\text { tion of safety requirements. }\end{array}$} & $1^{\text {st }}$ & 4.46 & 0.50 & 89.20 & 2 \\
\hline & & $2^{\text {nd }}$ & 3.32 & 0.47 & 66.40 & 2 \\
\hline & & $3^{\text {rd }}$ & 2.20 & 1.19 & 44.00 & 2 \\
\hline \multirow{3}{*}{63} & \multirow{3}{*}{$\begin{array}{l}\text { Working in poor ventilation and dusty air } \\
\text { in confined spaces and workshops cause } \\
\text { nocomplications into the application of safety } \\
\text { requirements. }\end{array}$} & $1^{\text {st }}$ & 3.88 & 1.20 & 77.60 & 4 \\
\hline & & $2^{\text {nd }}$ & 1.76 & 0.63 & 35.20 & 5 \\
\hline & & $3^{\text {rd }}$ & 1,44 & 0,81 & 28,80 & 4 \\
\hline \multirow{3}{*}{64} & \multirow{3}{*}{$\begin{array}{l}\text { Terrain and topography in site cause no- } \\
\text { complications into the application of safety } \\
\text { requirements. }\end{array}$} & $1^{\text {st }}$ & 4.77 & 0.55 & 95.40 & 1 \\
\hline & & $2^{\text {nd }}$ & 4.26 & 0.45 & 85.20 & 1 \\
\hline & & $3^{\text {rd }}$ & 3.55 & 0.57 & 71.00 & 1 \\
\hline & \multirow{3}{*}{ The Overall of project environment factor } & $1^{\text {st }}$ & 4.20 & 0.31 & 84.00 & $R=0.33$ \\
\hline & & $2^{\text {nd }}$ & 2.79 & 0.19 & 55.80 & $R=0.07$ \\
\hline & & $3^{\text {rd }}$ & 2.04 & 0.68 & 40.80 & $R=0.49$ \\
\hline
\end{tabular}

The classifications for mean values in the upcoming Tables will be based on the following criteria as suggested by researcher as shown in Table 7:

Table 7: Mean values classification

\begin{tabular}{|c|c|c|}
\hline Weak & Moderate & High \\
\hline Mean Value $<3$ & $\begin{array}{c}3 \leq \text { Mean Value } \\
\leq 4\end{array}$ & Mean Value $<4$ \\
\hline
\end{tabular}

\section{RESULTS AND DISCUSSIONS}

Based on the analysis data shown in Table 6 the discussion of the results is carried out. The discussion of the output data analysis will focus on the construction contracting companies (first, second and third degree) independently and investigate its safety status. The overall RII and Mean values of the seven factors affecting the safety management for the three degrees' construction companies are presented in Figures-1 \& 2. Thestrong notification that the seven factors affecting safety addressed by this investigation have reflect a high degree of importance from the $1^{\text {st }}$ degree construction companies project management. The $2^{\text {nd }}$ degree construction companies project management provide a moderate concern about these factors. Whereas the project management of $3^{\text {rd }}$ degree construction companies have a weak degree of implication of these safety factors in their delay work.

\section{Data analysis for the factors affecting safety procedure of $1^{\text {st }}$ degree companies}

The Safety equipment and PPE was the most factors addressed as it ranked the first while rewards and penalties was the lowest factor. Consequently, the $1^{\text {st }}$ degree companies are keen to provide all safety equipment on site. 


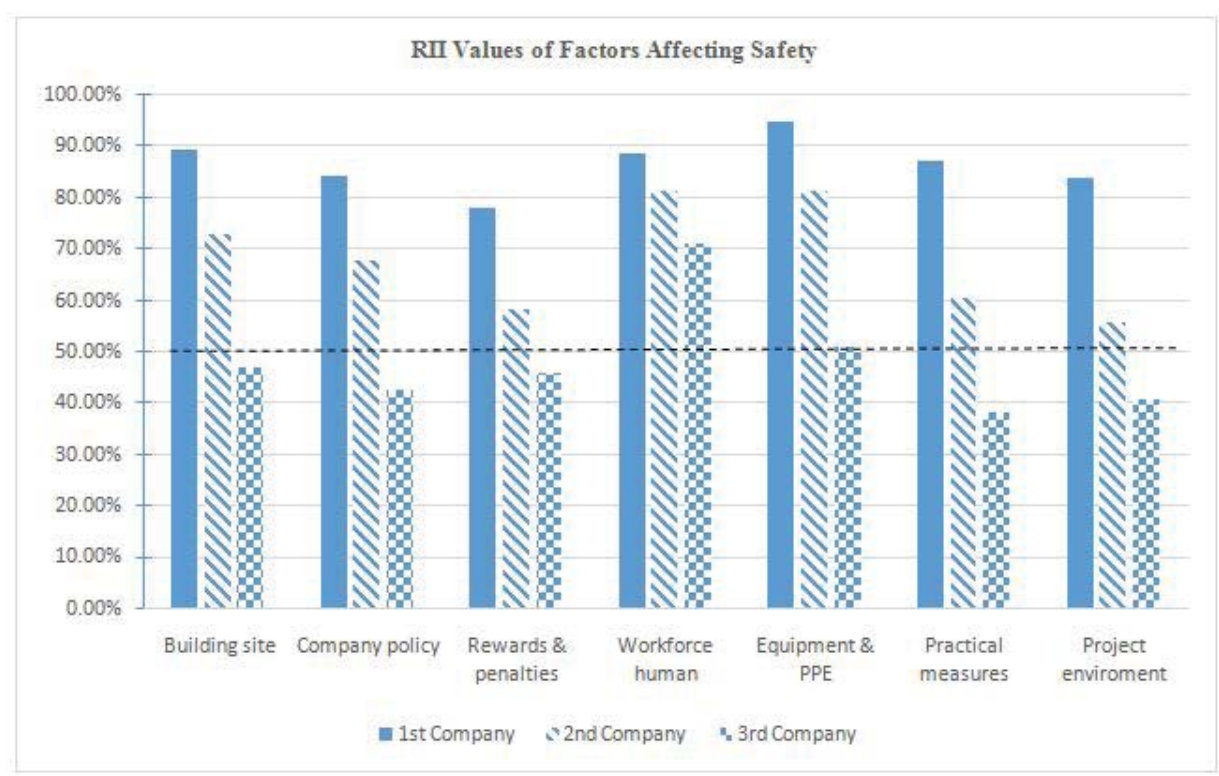

Figure 1: Ranking according to RII values for the three degrees' companies

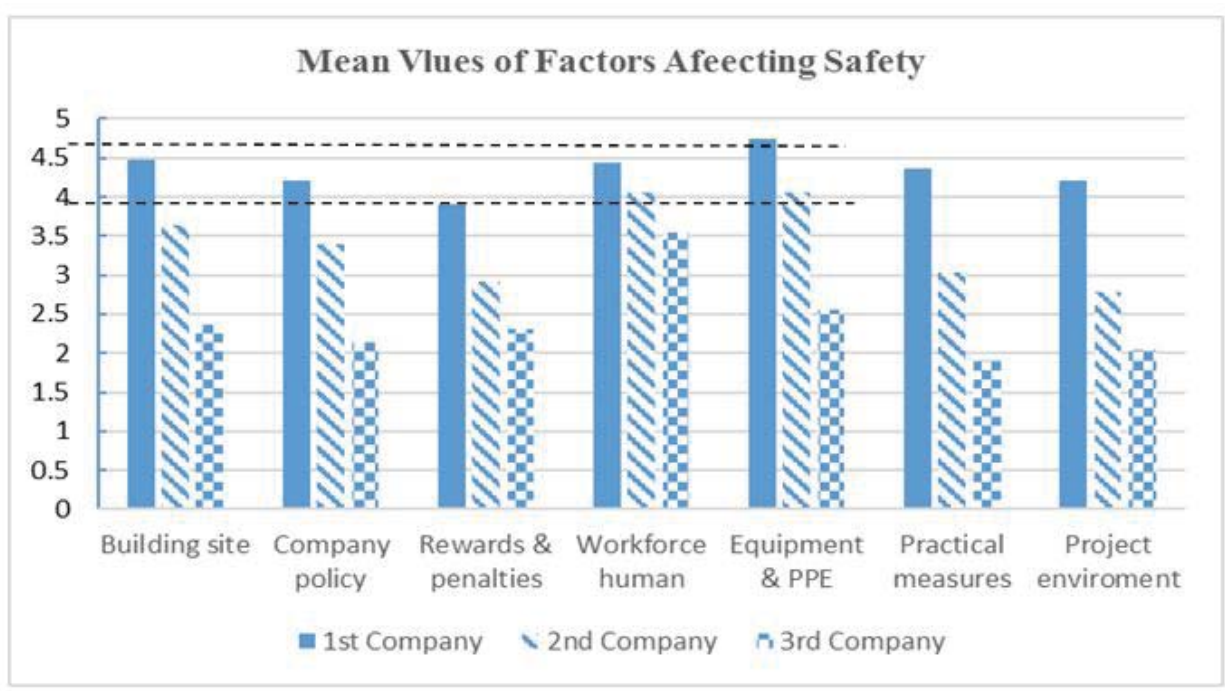

Figure 2: Ranking according to Mean values for the three degrees' companies

The following sub factors have a weak degree of recognized by the company's safety policy: the daily meetings in building site safety procedure. In company's safety policy procedure, the sub factors; modification, reviewing and updating and following the OSHA or OHSAS standards. In reward and penalties, the sub factors; rewarding committed workers to safety policy with cash bonus and rewarding the company due to safety performance. Perhaps these procedures require a countless commitment and follow up and efforts.

\section{Data analysis for the factors affecting safety procedure of $2^{\text {nd }}$ degree companies}

Three factors have a weak degree of distinguished by the company's safety policy: rewards and penalties, practical safety measure and project environment. Consequently, these processes involve lot of funding, commitment, follow up and efforts. In addition to what revealed in section
5.1, the following sub factors have a weak degree reorganization by the company's safety policy: the layout and scheme for project and availability of safety officer in building site safety procedure. In company safety policy; the sub factors availability of specialized officer and overtime working hours. In workforce human factor the application of safety instructions on site. This reflecting obvious neglect for the priority of safety in company policy.

\section{Data analysis for the factors affecting safety procedure of $3^{\text {rd }}$ degree companies}

All factors except the workforce human factor having weak degree ofidentification by the company's policy. This mean most $3^{\text {rd }}$ degree companies which represent $43 \%$ of total construction companies in Jordan working without any standardized or fixed criteria for safety policy. The development of safety policy by these companies involves lot of support, obligation, observation and determinations. 


\section{CONCLUSIONS}

The paper investigates the factors effecting safety policy of building construction companies in Jordan, and identifying the level of attention in applying the safety related factors. The conclusions drawn are:

1. The management of the $1^{\text {st }}, 2^{\text {nd }}$ and $3^{\text {rd }}$ degree construction companies in Jordan reflect high, moderate and weak degree of importance respectively to the seven factors affecting safety policy addressed by this investigation.

2. The following sub factors have a weak degree of recognized by all companies' safety policy;(i)The daily meetings to discuss safety requirements, (ii) Modification, reviewing and updating and following the OSHA or OHSAS standards, and (iii)Rewarding committed workers to safety policy with cash bonus.

3. The safety policy of $66 \%$ of the construction companies working in Jordan are below the international requirements and $43 \%$ of them are without any standardized or fixed criteria for safety policy.

\section{REFERENCES}

1. Mohamed A.J. Improving Safety Management System for Building Construction Projects in Jordan. MSc. Thesis, Isra University, Amman, Jordan; 2014.

2. El-Mashaleh M.S, Al-Smadi B.M, Hyari K H \& Rababeh S.M. Safety Management in the Jordanian Construction Industry. Jordan J. of Civil Engineering 2010; Vol.4, No.1: 47- 54

3. Senouci A, Al-Abbadi I \& Eldina N. Safety Improvement on Building Construction Sites in Qatar. Creative Construction Conference 2015; Procedia Eng. 123: 504- 509.

4. Al Haadir S \& Panuwatwanich K. Critical Success Factors for Safety Program Implementation among Construction Companies in Saudi Arabia. The Twelfth East Asia-Pacific Conference on Structural Engineering and Construction 2011; Procedia Eng. 14: 148- 155.

5. Zolfagharian S, Ressang A, Irizarry J, Nourbakhsh M \& Zin R.M. Risk Assessment of Common Construction Hazards among Different Countries. Sixth International Conference on Construction in the 21st Century 2011; Kuala Lumpur, Malaysia: 151- 160.

6. El-nagar R, Hosny H \& Askar H.S. Development of a Safety Performance Index for Construction Projects in Egypt. American Journal of Civil Engineering and Architecture 2015; Vol.3, No.5: 182-192.

7. Hasan A \& Jha K.N. Safety incentive and penalty provisions in Indian construction projects and their impact on safety performance. International J. of Injury Control and Safety Promotion 2013; Vol.20, Issue 1: 3- 12.
8. Aksorn T \& Hadikusumo B.H.W. Critical success factors influencing safety program performance in Thai construction projects. Safety Science J. 2008; Vol.46, Issue 4: 709-727.

9. Nord $H$, Wiitavaara $B, H 6 g b e r g ~ H$ \& Westerling $R$. A cross-sectional study of factors influencing occupational health and safety management practices in companies. Safety Science J. 2017; Vol.95: 95-103.

10. Chen $Y$, McCabe B \& Hyatt D. Impact of individual resilience and safety climate on safety performance and psychological stress of construction workers: A case study of the Ontario construction industry. Journal of Safety Research 2017; Vol.61: 167- 176.

11. Sunindijoa R.Y. Improving safety among small organizations in the construction industry: key barriers and improvement strategies. The 5th International Conference of Euro Asia Civil Engineering Forum 2015; Procedia Engineering 125: 109- 116.

12. Ozmec M.N, Karlsen I.L, Kines P, Andersen L.P.S \& Nielsen K.J. Negotiating safety practice in small construction companies. Safety Science J. 2015; Vol.71: 275- 281

13. Ayessaki W.Y \& Smallwood J. Influencing Workers' Performance through Health and Safety Interventions. $7^{\text {th }}$ International Conference on Engineering, Project, and Production Management 2017; Procedia Engineering 182: 42- 49.

14. Endroyo B, Surajib A \& Besaric M.S. Model of the maturity of pre-construction safety planning. Sustainable Civil Engineering Structures and Construction Materials 2017; Procedia Engineering 171: 413418.

15. Israel G.D. Program Evaluation and Organizational Development, Institute of Food and Agricultural Sciences (IFAS) 2009. Department of Agricultural Education and Communication, and extension specialist, University of Florida, Gainesville 32611.

16. George D. \& Mallery P. SPSS for windows step by step, A sample Guide \& Reference, (Fourth Edition) 2003; Allyn \& Bacon Publication, Canada, P231.

17. MacMillan A., Preston D., Wolfe J. \& Yu S. Basic statistics: mean, median, average, standard deviation, z-scores, and p-value 2006; SCRIBD, P28.

18. Iyer, K.C. \& Jha, K.N. Factors Affecting Cost Performance, Evidence from Indian Construction Projects. International J. of Project Management 2005; Vol. 23, Issue 4: 283-295.

Paper submitted: 04.10.2019.

Paper accepted: 09.03.2020.

This is an open access article distributed under the CC $B Y-N C-N D 4.0$ terms and conditions. 